\title{
PENGARUH LOCUS OF CONTROL EKSTERNAL TERHADAP IMPULSIVEBUYING PADA MAHASISWA DENGAN JENIS KELAMIN SEBAGAI VARIABEL MODERATOR
}

\author{
Lusi Tania Agustin \\ Universitas Mercu Buana Yogyakarta \\ Email: lusitaniaagustin5@gmail.com \\ Sarsono \\ Universitas Mercu Buana Yogyakarta \\ Email: sarsono@gmail.com
}

\begin{abstract}
This study aims to examine the effect of external locus of control based on students' gender towards impulsive buying. The subjects of this study are 80 students in the Special Region of Yogyakarta, aged 17-21 years. The Impulsive Buying and External Scales of Locus of Control were the instruments of this research. Simple linear regression analysis used as the data analysis. The results showed that external locus of control had a significant influence on impulsive buying in students, with $F$ count of 56.702 and $p$ $=0.000(0<0.010)$. This showed a significant influence between impulsive buying of clothing products with external locus of control on students. There is a positive influence between external locus of control on impulsive buying and gender as a moderator variable. The hypothesis proposed in this study is acceptable. It is concluded that between impulsive buying and external locus of control occurs because of causality or influence each other.
\end{abstract}

Key Words: Impulsive buying, external locus of control

\section{PENDAHULUAN}

Pentingnya untuk memenuhi kebutuhan fisik membuka peluang bagi para pengusaha di bidang ritel. Usaha ritel adalah segala aktivitas yang melibatkan proses menjual barang ataupun jasa dalam jumlah kecil ataupun satuan secara langsung kepada konsumen (Semuel, 2005). Di kota-kota besar seperti Yogyakarta, industri ritel mengembangkan tempat berbelanja yang memberi nilai tambah berupa hiburan dan kenyamanan, yaitu mall. Mall merupakan suatu tempat berkumpulnya para pengusaha ritel yang memiliki fungsi sebagai sarana pemenuhan kebutuhan-kebutuhan individu maupun keluarga (Ma'aruf,
2005).

Konsumen menggunakan produk atau jasa tidak hanya sebagai pemenuhan kebutuhan, namun juga karena keinginan semata yang belum tentu berguna nantinya. Selain itu, mall dapat memuaskan rasa penasaran manusiawi akan hal baru. Pada satu sisi, berdirinya mall merupakan upaya dari pemerintah daerah untuk menggerakan pertumbuhan ekonomi daerah. Mall sendiri terdiri atas beragam usaha seperti toko pakaian, toko mainan, toko makanan, toko buku, taman bermain prabayar, bioskop, department store, dan sejenisnya (Widawati, 2011).

Mahasiswa merupakan bagian dari masa remaja. Remaja yang di dalam 
bahasa aslinya disebut adolescene, berasal dari bahasa Latin adolescene (kata bendanya, adolescentia yang berarti remaja) yang mental, emosional, sosial, dan fisik (Hurlock, 2004). Pada masa remaja diantaranya mulai mencari identitas diri, sehingga seseorang yang berada dalam masa remaja artinya tumbuh untuk mencapai kematangan. Istilah adolescene mempunyai arti yang lebih luas, mencakup kemantangan akan sangat mudah terpengaruh oleh berbagai hal di sekelilingnya, baik itu yang positif maupun yang negatif. Pada usia tersebut, mereka membutuhkan pengakuan dari lingkungan sosialnya, masih dalam tahap pencarian jati diri, dan masih dalam keadaan emosi yang labil, sehingga apapun keputusan yang dilakukan termasuk keputusan membeli didominasi oleh emosi sesaat (Hurlock, 2004).

Mahasiswa merupakan sekelompok remaja yang mulai memasuki tahap dewasa awalnya. Pada masa kuliah, mahasiswa beralih dari sifat ketergantungan menuju sifat mandiri secara keuangan. Mahasiswa memiliki masalah keuangan yang kompleks karena sebagian besar mahasiswa belum memiliki pendapatan, cadangan dana yang dimiliki juga terbatas untuk digunakaan setiap bulannya, keterlambatan uang kiriman dari orang tua, atau uang bulanan habis sebelum waktunya. Hal tersebut bisa disebabkan oleh kebutuhan yang tidak terduga, ataupun disebabkan pengelolaan keuangan pribadi yang salah dikarenakan tidak adanya penganggaran dalam hidup, serta gaya hidup dan pola konsumsi boros (Nababan \& Sadalia, 2013).

Banyaknya iklan-iklan yang menggiurkan, menyebabkan timbulnya keinginan dalam diri mahasiswa untuk membeli suatu produk, salah satunya produk pakaian. Jika mereka tidak bisa menahan keinginan yang muncul dalam dirinya, maka ia cenderung memanfaatkan uangnya untuk membeli produk yang diinginkan dan belum tentu dibutuhkannya. Padahal seharusnya mahasiswa dituntut agar mampu memanfaatkan uang untuk memenuhi kebutuhan pendidikannya (Nuraeni, 2015).

Salah satu produk yang sering dibeli tanpa terencana adalah pakaian. Pakaian merupakan salah satu kebutuhan pokok bagi manusia yang merupakan alat penutup tubuh yang akan memberikan kepantasan, kenyamanan serta keamanan. Adanya mode yang terus berkembang dapat menarik konsumen agar mencoba dan pada akhirnya membeli produk tersebut tanpa rencana. Peminat produk pakaian sendiri tidak hanya bagi orang yang sudah bekerja saja tapi juga diperuntukkan bagi semua kalangan, termasuk mahasiswa (Anjani, 2012).

Impulsive buying merupakan pembelian secara tiba-tiba, ada dorongan yang kuat untuk membeli secara spontan dan disertai perasaan senang dan gembira (Rook \& Fisher, 1995). Selain itu, impulsive buying didefinisikan sebagai suatu kondisi yang terjadi ketika individu mengalami perasaan terdesak secara tiba-tiba yang tidak dapat dilawan (Solomon \& Rabolt, 2009). Beatty \& Ferrel (1998) berpendapat bahwa impulsive buying biasanya dilakukan tanpa adanya perencanaan sebelumnya untuk membeli produk tertentu atau memenuhi kebutuhan tertentu.

Lebih lanjut Rook menjelaskan adanya aspek dari impulsive 
buying, adalah: 1) spontanitas, yaitu tindakan tidak terduga yang memotivasi konsumen untuk membeli saat itu juga, 2) kekuatan, dorongan/tekanan, dan perasaan yang hebat, yaitu perilaku yang terdapat motivasi untuk mengesampingkan hal-hal lain dan bertindak secepatnya, 3) perasaan senang dan terangsang, yaitu desakan mendadak untuk membeli yang disertai dengan emosi menggairahkan dan menggetarkan, dan 4) mengabaikan konsekuensi, yaitu desakan untuk membeli dapat mejadi begitu sulit ditolak sehingga akibat yang mungkin negatif diabaikan.

Kebiasaan belanja yang berlebihan dapat mengakibatkan hutang menumpuk. Tanpa disadari pengeluaran membengkak akibat dorongan belanja, bahkan tidak sedikit pula mahasiswa yang rela meminjam uang kepada orang lain dengan berbagai alasan demi membeli pakaian yang diincarnya. Bagi mahasiswa yang memiliki kebiasaan belanja yang berlebihan dapat mengakibatkan uang bulanan habis di pertengahan bulan. Uang belanja bulanan semestinya dapat dibagi rata sehingga mampu menutup pengeluaran setiap harinya secara seimbang, namun jika tidak digunakan dengan bijaksana dapat merugikan mahasiswa di kemudian hari (Nababan \& Sadalia, 2013).

Jika mengacu pada faktor-faktor yang dapat memengaruhi munculnya impulivse buying maka Loudon \& Bitta (1993), mengemukakan hal-hal di bawah ini sebagai faktor-faktor munculnya impulivse buying, yaitu; 1) karakteristik produk, meliputi barang tersebut memiliki harga yang rendah, ukurannya kecil dan ringan serta mudah disimpan, 2) karakteristik pemasaran, meliputi pemasangan iklan besar-besaran dan material yang didiskon, serta posisi barang yang dipamerkan, 3) karakteristik konsumen, meliputi kepribadian konsumen, Robbins (2007) menjelaskan bahwa salah satu atribut kepribadian yang berkaitan dengan penentu sukses atau gagalnya seseorang adalah locus of control (lokus kendali), karakteristik konsumen selanjutnya yaitu demografis (jenis kelamin dan usia), dan faktor sosioekonomi.

Pada penelitian ini penulis menggunakan salah satu faktor yaitu locus of control dimana sebagai kepribadian konsumen berdasarkan karakteristik konsumen pada faktor yang mempengaruhi impulsive buying (Loudon \& Bitta, 1993). Locus of control merupakan salah satu atribut kepribadian yang telah dijumpai sebagai peramal yang ampuh dari perilaku dalam organisasi yaitu atribut yang berkaitan dengan tempat dimana seseorang membayangkan tempat kedudukan kendali (locus of control) dalam kehidupannya. Menurut Rotter (dalam Phares, 1978) locus of control terbagi menjadi dua jenis yaitu: 1) locus of control internal, yaitu seseorang yang selalu menghubungkan peristiwa yang dialaminya dengan faktor dalam dirinya, dan 2) locus of control eksternal, yaitu letak kendali diri yang menfokuskan bahwa keberhasilan atau kegagalannya berasal dari luar dirinya.

Berdasarkan hasil penelitian Widawati (2011) pada umumnya konsumen memiliki perilaku impulsive buying yang rendah dengan locus of control cenderung internal. Konsumen yang berperilaku impulsive buying rendah pada umumnya memiliki locus of control internal sedangkan kelompok konsumen 
yang berperilaku impulsive buying tinggi, pada umumnya memiliki locus of control eksternal. Oleh karena itu penulis tertarik untuk meneliti pengaruh locus of control eksternal terhadap impulsive buying.

Jika mengacu pada aspek-aspek locus of control eksternal maka Rotter (dalam Phares, 1978) membaginya menjadi tiga aspek yaitu: 1) nasib, yaitu seseorang yang menganggap kesuksesan dan kegagalan yang dialami telah ditakdirkan, 2) keberuntungan, yaitu seseorang mereka menganggap bahwa setiap orang memiliki keberuntungan, dan 3) pengaruh orang lain, yaitu seseorang yang menganggap bahwa orang yang memiliki kekuasaan dan kekuatan yang lebih tinggi mempengaruhi perilaku mereka dan sangat mengharapkan bantuan orang lain.

Faktor lain yang mempengaruhi impulsive buying adalah faktor demografis, pada penelitian ini penulis fokus pada salah satu faktor demografis yaitu jenis kelamin. Alasan penulis hanya menggunakan jenis kelamin sebagai salah satu factor demografis karena jenis kelamin merupakan variabel yang ditetapkan berdasarkan proses penggolongan. Variabel ini bersifat diskret dan saling pilah antara kategori satu dengan kategori yang lain, yaitu perempuan dan laki-laki.

Tujuan penelitian ini yaitu: a) menguji pengaruh locusof control eksternal terhadap impulsive buying pada mahasiswa, b) menguji pengaruh locus of control eksternal terhadap impulsive buying pada perempuan, c) menguji pengaruh locus of control eksternal terhadap impulsive buying pada laki-laki, d) menguji perbedaan impulsive buying antara mahasiswa perempuan dan laki-laki, dan e) menguji perbedaan locusof control eksternal antara mahasiswa perempuan dan laki-laki.

Berdasarkan ulasan di atas maka hipotesis dalam penelitian ini adalah: a) terdapat pengaruh positif locusof control eksternal terhadap impulsive buying pada mahasiswa, b) terdapat pengaruh locus of control eksternal terhadap impulsive buying pada perempuan, c) terdapat pengaruh locus of control eksternal terhadap impulsive buying pada laki-laki, d) terdapat perbedaan impulsive buying antara mahasiswa perempuan dan lakilaki, dan e) terdapat perbedaan locusof control eksternal antara mahasiswa perempuan dan laki-laki.

\section{METODE PENELITIAN}

\begin{tabular}{llr}
\multicolumn{2}{c}{ Metode Penelitian yang } \\
digunakan pada penelitian ini \\
merupakan
\end{tabular} kuantitatif. Pengumpulan data dalam metode ini menggunakan skala likert, dimana penelitian ini terdapat 2 skala yaitu skala impulsive buying dan locus of control eksternal. Jumlah subjek dalam penelitian ini yaitu sebanyak 80 responden. Instrumen penelitian menggunakan skala impulsive buying dengan 24 aitem dinyatakan valid dan hasil Alpha Cronbach sebesar 0,956. Selanjutnya pada skala locus of control eksternal terdiri dari 24 aitem dan terdapat 22 aitem yang valid dengan dan hasil Alpha Cronbach sebesar 0,852.

\section{HASIL PENELITIAN DAN PEMBAHASAN}

Pada penelitian ini sebelum melakukan analisis regresi linier sederhana dan uji-t (independent samples t- 
test) untuk menguji hipotesis, terlebih dahulu dilakukan uji asumsi yang meliputi uji normalitas dan uji linieritas. Hasil uji normalitas untuk variabel impulsive buying diperoleh nilai SD sebesar 0,053 dengan nilai signifikansi sebesar $0,200$ ( $p>0,050)$. Pada variabel locus of control eksternal diperoleh nilai SD sebesar 0,096 dengan nilai signifikansi sebesar $0,065(p>0,050)$, sehingga dapat disimpulkan bahwa data variabel impulsive buying dan locus of control eksternal terdistribusi secara normal. Berdasarkan uji liniearitas yang telah dilakukan, diperoleh nilai F sebesar 55,659 dan nilai signifikansi pada linearity ( $p$ ) sebesar $0,000 \quad(p<0,050)$, sehingga dapat disimpulkan bahwa antara variabel locus of control eksternal dan impulsive buying terdapat hubungan yang linier. Hasil uji hipotesis 1, 2, dan 3 menggunakan analisis regresi linier sederhana, sedangkan hasil uji hipotesis 4 dan 5 menggunakan uji-t (independent-sample t test).

Berdasarkan hasil penelitian ini dapat diketahui bahwa ada hubungan positif antara locus of control eksternal terhadap impulsive buying pada mahasiswa di Yogyakarta dengan koefisiendeterminasi atau $R$ square sebesar 0,421 atau $42,1 \%$ yang artinya impulsive buyingdipengaruhi locus of control eksternal sebesar $42,1 \%$, sehingga terdapat faktor lain sebesar $57,9 \%$ yang dapat mempengaruhiimpulsive buyingpada mahasiswa di Yogyakarta. Faktor lain yang mempengaruhi impulsive buyingpada mahasiswa di Yogyakartaadalah karakteristik produk, karakteristik pemasaran, dan karakteristik konsumen.

Sesuai dengan hipotesis kedua bahwa terdapat pengaruhlocus of control eksternal terhadap impulsive buying pada perempuan, ditemukan nilai $\mathrm{r}$ sebesar 0,619 , hasil koefisiendeterminasi atau $R$ square sebesar 0,383 yang artinya impulsive buyingdipengaruhi locus of control eksternal pada perempuan sebesar 38,3\% sehingga terdapat faktor lain sebesar 61,7\% yang dapat mempengaruhiimpulsive buyingpada perempuan.

Selanjutnya pada hipotesis ketiga ditemukan hasil bahwa terdapat pengaruhlocus of control eksternal terhadap impulsive buying pada laki-laki, ditemukan nilai $r$ sebesar 0,565, hasil koefisiendeterminasi atau $R$ square sebesar 0,320 yang artinya impulsive buyingdipengaruhi locus of control eksternal pada laki-laki sebesar 32\% sehingga terdapat faktor lain sebesar $68 \%$ yang dapat mempengaruhiimpulsive buyingpada laki-laki. Jika pengaruh locus of control eksternal terhadap impulsive buying ditinjau dari jenis kelamin, maka ditemukan bahwa nilai r pada perempuan lebih besar dibandingkan nilai r pada lakilaki $(0,619>0,565)$. Jadi dapat disimpulakan bahwa pengaruh locus of control eksternal terhadap impulsive buying pada perempuan lebih besar dibandingkan laki-laki.

Konsumen seringkali membeli suatu produk karena dorongan emosional yang sangat kuat dan tiba-tiba. Hal ini tergolong impulsive buying atau pembelian yang tidak terencana (Rahmasari, 2010). Beberapa penelitian menunjukkan bahwa impulsive buying dapat dipengaruhi oleh faktor internal maupun eksternal. Salah satu faktor yang dapat mempengaruhi impulsive buying adalah karakteristik konsumen, meliputi kepribadian konsumen, Robbins (2007) menjelaskan bahwa salah satu atribut kepribadian yang berkaitan dengan penentu sukses 
atau gagalnya seseorang adalah locus of control (lokus kendali). Berdasarkan penelitian widawati (2011) terkait locus of control, faktor dominan yang dapat mempengaruhi impulsive buying adalah locus of control eksternal. Menurut McElroy \& Dowd, 2007) hal tersebut dapat terjadi karena individu dengan locus of control eksternal yang tinggi cenderung memiliki rasa tanggung jawab yang dalam pengambilan keputusan.

Impulsive buying merupakan pembelian yang mengaitkan keputusan pembelian dengan emosi dan dapat terjadi karena ketidakmampuan individu dalam mengontrol keinginan untuk membeli, dimana faktor pemicu pembelian yang berasal dari luar diri mereka. Berdasarkan jenis kelamin, diperoleh gambaran bahwa sejalan dengan sifat wanita yang menyenangi belanja, maka dibanding sampel laki-laki, konsumen wanita tetap memiliki kecenderungan impulsive buying tinggi yang lebih banyak dibanding konsumen laki-laki. Sisi emosi yang cenderung mendominasi perasaan dan pikiran wanita menjadi sumber mengapa mereka menjadi mudah tergugah oleh stimulasi dari lingkungan yang ditawarkan, sekali pun mereka menyadari bahwa barangbarang tersebut belum tentu dibutuhkan. Pada hasil penelitian ini juga ditemukan bahwa perempuan memiliki locus of control eksternal yang tinggi dibanding laki-laki.

Konsumen perempuan menjadi figur pelaku yang berpeluang besar untuk melakukan impulsive buying. Jika dibandingkan dengan laki-laki, perempuan cenderung lebih banyak dipengaruhi oleh sisi emosionalitas dibandingkan rasionalitas. Emosionalitas memiliki hubungan yang erat dengan konsep impulsive buying yang dipaparkan oleh (Engel,1995). Perempuan juga cenderung memiliki kemampuan yang lebih rendah dalam mengontrol diri sehingga cenderung memiliki locus of control eksternal yang tinggi dibandingkan laki-laki. Dengan demikian jelaslah bahwa perempuan mempunyai pengaruh locus of control eksternal yang tinggi terhadap impulsive buying dibandingkan laki-laki.

Selanjutnya berdasarkan hasil penelitian ini diketahui bahwa terdapat perbedaan impulsive buying pada mahasiswa perempuan dan laki-laki secara signifikan, dibuktikan oleh hasil nilai $t$ hitung sebesar $-6,856$ dan taraf signifikansi $\quad p=0,000 \quad(p<0,050)$, yang berarti bahwa terdapat perbedaan impulsive buying ditinjau dari jenis kelamin pada mahasiswa, serta diperkuat oleh hasil rerata (mean) impulsive buying perempuan sebesar 102,95 termasuk kategori tinggi, sedangkan nilai rata-rata atau meanimpulsive buying laki-laki sebesar 90,50 termasuk kategori sedang, sehingga dapat disimpulkan hipotesis keempat dalam penelitian ini dapat diterima.

Hasil penelitian uji-t (independent samples $t$-test) dalam penelitian ini didukung oleh hasil penelitian Harviona (2010) yang menunjukkan bahwa terdapat perbedaan yang signifikan impulsive buying laki-laki dan perempuan, dengan konsumen perempuanlebih sering melakukan impulsive buyingdibandingkan konsumen laki-laki. Hasil penelitian ini juga sesuai dengan penelitian Mulyono (2013) yang meneliti tentang faktor demografis dalam perilaku impulsif, menemukan hasil bahwa terdapat perbedaan impulsive buying jika ditinjau dari jenis kelamin. Hasil penelitian ini 
juga memperlihatkan adanya kesesuaian dengan anggapan umum bahwa perempuan memiliki dominasi dalam segi afeksi. Alasan lain mengapa perempuan lebih impulsive buying dibanding laki-laki dikarenakan perempuan memiliki perasaan yang positif ketika melakukan pembelian. Selain itu hasil penelitian ini juga terbukti sesuai dengan penelitian Kollat \& Willett di tahun 1967 bahwa perempuan memiliki daya tahan yang lebih rendah dibanding laki-laki dalam upayanya menahan dorongan hati untuk berbelanja yang disebabkan karena secara umum perempuan lebih banyak berperan dalam berbelanja (Coley \& Burgess, 2003).

Hasil penelitian ini memiliki perbedaan dengan hasil penelitian yang dilakukan oleh Lina (1997), maupun Anin (2008) yang menemukan bahwa tidak ada perbedaan impulsive buying remaja jika dilihat dari jenis kelamin. Hal ini diterangkan dengan munculnya fenomena pria metroseksual, dimana pria saat ini berperilaku seperti wanita dalam urusan penampilan dan merawat tubuh (Mulyono, 2013).

Selanjutnya pada penelitian ini ditemukan hasil bahwa terdapat perbedaan locus of control eksternal pada mahasiswa perempuan dan laki-laki secara signifikan, dibuktikan oleh hasil nilai $t$ hitung sebesar $-3,302$ dan taraf signifikansi $p=0,010 \quad(p<0,050)$, yang berarti bahwa terdapat perbedaan locus of control eksternal ditinjau dari jenis kelamin pada mahasiswa, serta diperkuat oleh hasil rerata (mean) locus of control eksternal perempuan sebesar 70,0500 termasuk kategori tinggi, sedangkan nilai rata-rata atau mean impulsive buying lakilaki sebesar 65,1000 termasuk kategori sedang.
Hasil penelitian ini didukung oleh penelitian terdahulu, berdasarkan hasil penelitian (Youn \& Faber, 2000) ditemukan hasil bahwa perempuan cenderung memiliki locus of control eksternal yang tinggi dibanding laki-laki. Namun pada penelitian Sumijah (2015) yang meneliti tentang locus of control pada masa dewasa, tidak ditemukan perbedaan locus of control jika ditinjau dari jenis kelamin. Secara umum hasil penelitian menunjukkan guru laki-laki dan perempuan yang menjadi responden memiliki locus of kontrol eksternal yang rendah dan juga menunjukkan bahwa tidak ada perbedaan secara bermakna antara locus of control guru laki-laki dan perempuan.

\section{PENUTUP}

Locus of control eksternal memiliki pengaruh yang signifikan terhadap variabel impulsive buying. Semakin tinggi locus of control eksternal menunjukkan semakin tinggi impulsive buying mahasiswa terhadap produk pakaian. Sebaliknya semakin rendah locus of control eksternal, maka semakin rendah impulsive buying mahasiswa terhadap produk pakaian. Pengaruh yang signifikan terlihat pada perempuan, hal tersebut dapat terjadi karena perempuan dengan kontrol tingkah laku eksternal lebih mudah terstimulasi oleh faktor diluar dirinya, sehingga peran keluarga, teman, saran ahli, iklan, tampilan kemasan produk, dan sampel produk. Ini menunjukan bawa impulsive buying perempuan lebih tinggi dari laki-laki. Begitu juga dengan locus of control eksternal pada perempuan lebih tinggi dari locus of control eksternal lakilaki.

Bagi mahasiswa, yang locus of control 
eksternal tinggi diharapkan dapat membatasi diri sehingga tidak sampai melakukan imitasi berlebih pada orang lain. Locus of control eksternal yang tinggi tidak harus dengan mode, tetapi juga dapat disalurkan ke hal-hal yang lain. Mahasiswa yang memasuki masa dewasa awal sudah dituntut untuk mampu memilah antara kebutuhan dan keinginan, dimana kebutuhan mahasiswa lebih diberatkan pada pembelian yang mendukung performa mereka dalam perkuliahan, seperti pembelian bukubuku yang bermanfaat. Melihat sumbangan variabel locus of control eksternal sebesar $42,1 \%$, berarti masih ada faktor lain yang sangat mempengaruhi, maka disarankan kepada peneliti selanjutnya yang tertarik dengan permasalahan serupa untuk meneliti faktor-faktor lain tersebut. Misalnya faktor sosial, budaya, konomi, dan sebagainya.

\section{REFERENSI}

Anin, F,A., Rasimin BS., \& Atamimi N. tt. (2008). Hubungan Self-Monitoring dengan Imppulsive Buying terhadap Produk Fashionpada Remaja. Jurnal Psikologi. 35(2), 181-193.

Anjani, B. B. (2012). Analisis Faktor-faktor yang berpengaruh terhadap keputusan investasi pada perusahaan food and beverages di bursa efek Indonesia.Tesis. Semarang. Universitas Diponegoro.

Beatty, S. E., \& Ferrell, M. E. (1998). Impulse buying: modeling its precusors. Journal of Retailing. 74(2), 105-138.

Biaggio, A. M. B. (2004). Relationships between state-trait anxiety and locus of control- experimental studies with adults and children. International Journal of Behavioral Development, 8 (2), 153-166.

Coley, A., \& Burgess, B. (2003).Gender differences in cognitive and affective impulse buying.Journal of Consumer Psychology.12(4), 173-186.

Engel, J. F., Blackwell, R. D., \& Miniard, P.W. (1995). Perilaku konsumen, Edisi keenam (terjemahan). Jakarta: Binarupa Aksara.

Harviona, T. V. (2010). Perilaku pembelian impulsif produk pakaian masyarakat urban di kota Jakarta dan Bandung. Tesis. Jakarta. Universitas Indonesia.

Hurlock, Elizabeth B. (2004). Developmenral Psychology. Jakarta: Erlangga.

Lina., Haryanto, F Rosyid. (1997). Perilaku Konsumtif Berdasarkan Locus of Control pada Remaja Putri. Jurnal Psikologika. Vol 4, 7-8.

Loudon, D.L. \& Bitta, A. J. (1993). Consumer Behaviour Concept and Application (4th ed). Singapore: McGraww Hill.

Ma'aruf, H. (2005). Pemasaran ritel. Jakarta: PT. Gramedia Pustaka Utama.

McElroy, T., \& Dowd, K. (2007). Action orientation, consistency and feelings of

regret. Judgment and Decision Making,2(6), 333-341.

Mulyono, Fransisca. (2013). Faktor Demografis dalam Perilaku Pembelian Impulsif. Fakultas Ilmu Sosial dan Ilmu Politik, Universitas Katolik Prahyangan. Jurnal 8(1), 88105. 
Nababan, Daman \& Sadalia, Isfenti. (2013). Analisis Personal Financial Literacy dan Financial Behavior Mahasiswa Strata I Fakultas Ekonomi Universitas Sumatera Utara. Jurnal Media Informasi Manajemen. 1(1).

Nuraeni. (2015). Pengaruh Literasi Ekonomi, Kelompok Teman Sebaya dan Kontrol Diri terhadap Perilaku Pembelian Implusif untuk Produk Fashion pada Mahasiwa Fakultas Ekonomi Universitas Negeri Yogyakarta. Tesis. Fakultas Ekonomi Universitas Negeri Yogyakarta.

Phares.(1978). Locus of Control,dimension of Personality. New York: John Wiley \& Sons.

Rahmasari, Lisda. (2010). Menciptakan Impulse Buying. Jurnal Fakultas Ekonomi. Universitas AKI. Majalah Ilmiah Informatika. 1(3).

Robbins, Stephen P. (2007). Perilaku Organisasi. Indeonesia: PT Macanan Jaya

Rook, D. W. (1987). The Buying Impulse. The Journal of Consumer Research, 14(2). (1995). Normative influences on impulsive buying behavior. Journal of Consumer Research. 22(3),305-313.

Semuel, Hatane. (2005).Respon Lingkungan Belanja Sebagai Stimulus Pembelian Tidak Terencana pada Toko Serba Ada (Toserba).Jurnal Manajemen $\mathcal{E}$ Kewirausahaan, 7 (2) 152-170.

Solomon, M. R., \& Robolt, N. (2009). Consumer Behavior in Fashion (2ndedition). USA: Prentice hall.

Sumijah. (2015). Locus of control pada masa dewassa. Seminar Psikologi dan kemanusiaan. Psychology forum UMM. Vol. 8.

Widawati, Lisa. (2011). Analisis Perilaku Impulse Buying dan Locus of Control pada Konsumen di Carrefour Bandung. Jurnal Mimbar. 27(2), 125132.

Youn, S. \& Faber, R. J. (2000). Impulse buying: its relation to personality traits and cues. Advances in consumer research. Vol. 27. 
10 || Turast: Jurnal Penelitian dan Pengabdian Vol. 6, No. 1, Januari-Juli 2018 
